\title{
Migrated Intravesical Intrauterine Contraceptive Devices: A Case Series and a Suggested Algorithm for Management
}

\author{
Omar S. Akhtar ${ }^{1}$, Sabahat Rasool ${ }^{2}$, Syed Sajjad Nazir ${ }^{1}$ \\ 1. Department of Urology, Government Medical College, Srinagar, Srinagar, IND 2. Department of Obstetrics and \\ Gynaecology, Government Medical College, Srinagar, Srinagar, IND
}

Corresponding author: Omar S. Akhtar, omarakhtar@hsshcc.org

\section{Abstract \\ Introduction}

Intrauterine contraceptive devices (IUCD) are a commonly used, reversible, contraceptive method. Complications from insertion rarely include migration into the bladder. We report on two cases of intravesical migrated IUCD and present an algorithm for management based on recently published data.

\section{Materials and Methods}

The case records of two patients who underwent surgical procedures for migrated IUCD into the bladder were reviewed. A Pubmed search was performed to identify similar studies. A total of 25 papers met the criteria for inclusion.

\section{Results}

Both cases were managed with laparotomy and partial cystectomy. A review of literature suggests recently reported cases of IUCD migration are rising, with most cases having been reported in the last decade. Bladder calculus developing over the migrated IUCD is the most common presentation. Most cases have been managed using endourological techniques. A small number of cases have required open vesicolithotomy or laparoscopic surgery. Rarely, laparotomy has been required.

\section{Discussion}

IUCD migration into the bladder remains rare, however, recently the number of reported cases has risen. A thorough physical examination and radiological evaluation are warranted. Management is surgical in all cases. Most cases can be managed with endourological techniques. A treatment algorithm has been suggested in this paper based on recent data.

Review began 01/08/2021 Review ended 01/28/2021 Published 01/29/2021

(c) Copyright 2021

Akhtar et al. This is an open access article distributed under the terms of the Creative Commons Attribution License CC-BY 4.0., which permits unrestricted use, distribution, and reproduction in any medium, provided the original author and source are credited.

\section{Conclusion}

With the rising use of contraception worldwide, the incidence of IUCD migration is possibly going to increase. Treating doctors need to be aware of the possible complications that may arise from a migrated IUCD, including bladder calculi.

Categories: Obstetrics/Gynecology, Urology, Public Health

Keywords: intrauterine contraceptive device, bladder calculus, vesical calculus, migrated intrauterine device, contraception

\section{Introduction}

Intrauterine contraceptive devices (IUCD) are a popular method of contraception used by approximately $14.3 \%$ of women worldwide [1]. Insertion of an IUCD carries a risk of perforation in 1/1000 cases [1]. Migration of IUCD usually occurs after a uterine perforation, which may occur at the time of implanting the device, called primary perforation, or many years later, due to infection or device-related inflammation, called secondary perforation [2]. Migration into the peritoneal space is most reported [3,4]. Migration of the IUCD into the urinary tract is rare and has been reported in only a few dozen cases in the published literature as of 2020. When an IUCD migrates into the bladder, it may cause a local reaction, and deposition of calcium when it enters the lumen. This may progress and form a calculus over many years [5].

In this paper, we examine two cases of spontaneous IUCD migration into the bladder and then review the literature on the management of this rare complication.

\section{Materials And Methods}


The case records of two patients who had bladder involvement of migrated IUCD were studied. For a literature review, a search of terms, 'Intrauterine contraceptive device migration,' 'Urinary tract complications of intrauterine contraceptive devices,' 'Intrauterine contraceptive device migration in urinary bladder, 'Intravesical intrauterine device migration,' and 'Urinary bladder intrauterine contraceptive device,' were performed in Pubmed. Relevant studies in the English language were perused and studied and data collected.

\section{Results}

\section{Case 1}

This is a case of a 40-year-old female patient who was referred with a lost IUCD. On presentation, there was no fever, no urinary symptoms, and no menstrual irregularities. A physical examination was normal. An Xray revealed the IUCD (Copper-T) to be displaced outside the area of the uterus but within the pelvis. Ultrasonography (USG) performed confirmed that the uterine cavity was empty and showed an echogenic shadow suggestive of an IUCD on the right-side of the uterus. The kidneys, ureters, and bladder were normal. The patient was taken up for laparoscopic removal of the IUCD. During surgery, the IUCD was seen in the right parametrium, densely covered with adhesions. On mobilizing the IUCD, the IUCD was grasped but did not come out. A limb was found embedded in the right, lateral bladder wall. An urgent urological consult was called for. The procedure was converted into a laparotomy and the bladder mobilized on the right side. The IUCD limb was then isolated and the bladder wall marked with electrocautery, which was deepened using sharp dissection until the mucosa. The bladder wall and the IUCD were removed in total and the bladder wall repaired in three layers with absorbable sutures. A Foley catheter along with an intraperitoneal drain was left in situ. The patient made an uneventful recovery.

\section{Case 2}

A 35-year-old, para 3 patient presented with dysuria, frequency, and urgency. On history, she revealed that she had had an IUCD insertion around a year prior to the presentation but had forgotten about it. At the time of presentation, she was amenorrhoeic for three months, and a pregnancy test was positive. A USG performed showed a bladder calculus of about $1 \mathrm{~cm}$ in size. She was taken up for cystoscopic removal of the calculus. However, the calculus was found to be adherent to the bladder wall, and on gentle traction, revealed a limb suggestive of an IUCD limb (Figure 1). The patient was advised surgery, but as there was a risk to the fetus, she elected to postpone the surgery until after the delivery of the child. After completion of term, she was taken up for cesarean section delivery but again elected to postpone the IUCD surgery until after the baby was older. She came for follow-up six months after the cesarean section and was reinvestigated at the time. A contrast-enhanced CT scan was performed to rule out any other adjacent organ involvement (Figure 2). An elective exploratory laparotomy was performed, in which intra-operative findings revealed an anteriorly displaced IUCD, which was densely adherent to the anterior bladder wall. (Figure 3). A partial cystectomy was performed with excision of the adjacent bladder wall and the IUCD was removed in toto (Figure 4). A bladder repair was performed. An intraperitoneal drain, a supra-pubic catheter, and a Foley catheter were left in situ. The patient made an uneventful recovery and was symptom-free one year after surgery. 


\section{Cureus}

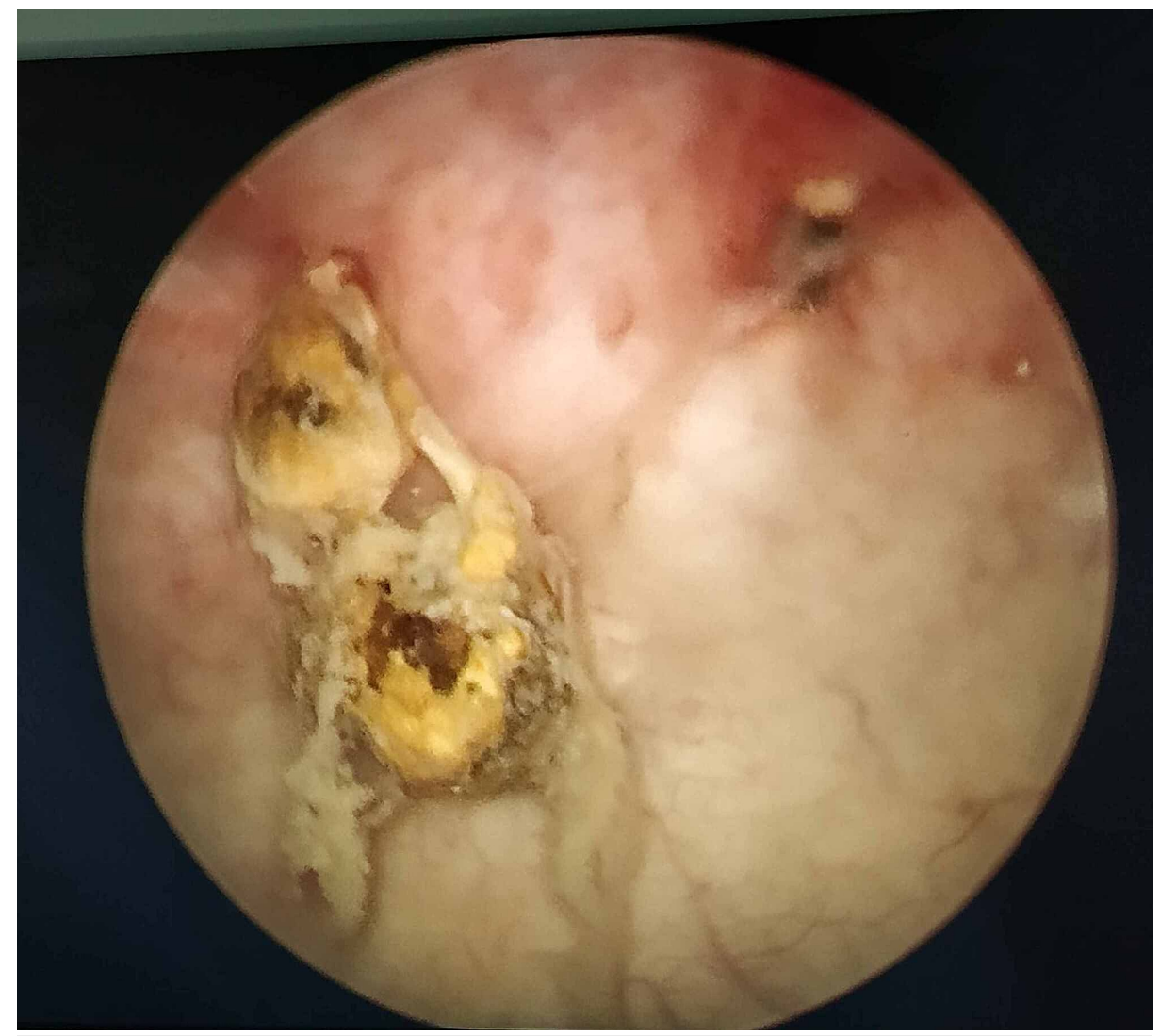

FIGURE 1: Cystoscopic image of Intrauterine contraceptive devices (IUCD) embedded in the bladder wall.

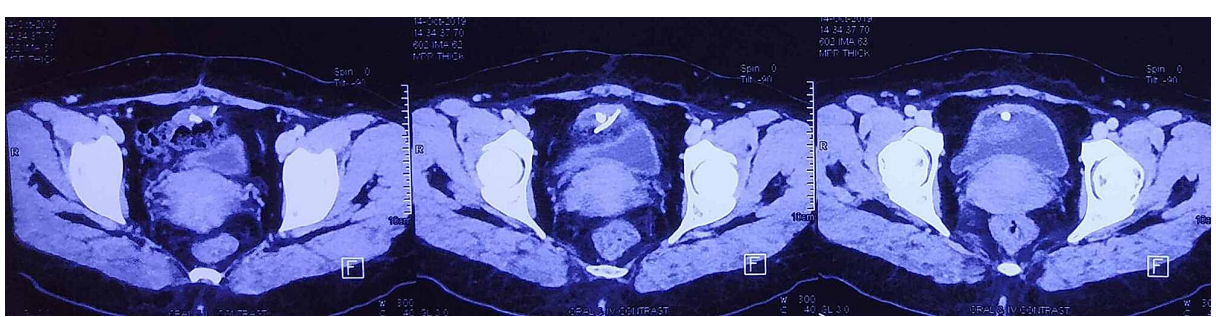

FIGURE 2: CT scan showing the Intrauterine contraceptive devices (IUCD) within the bladder lumen and traversing the bladder wall 


\section{Cureus}

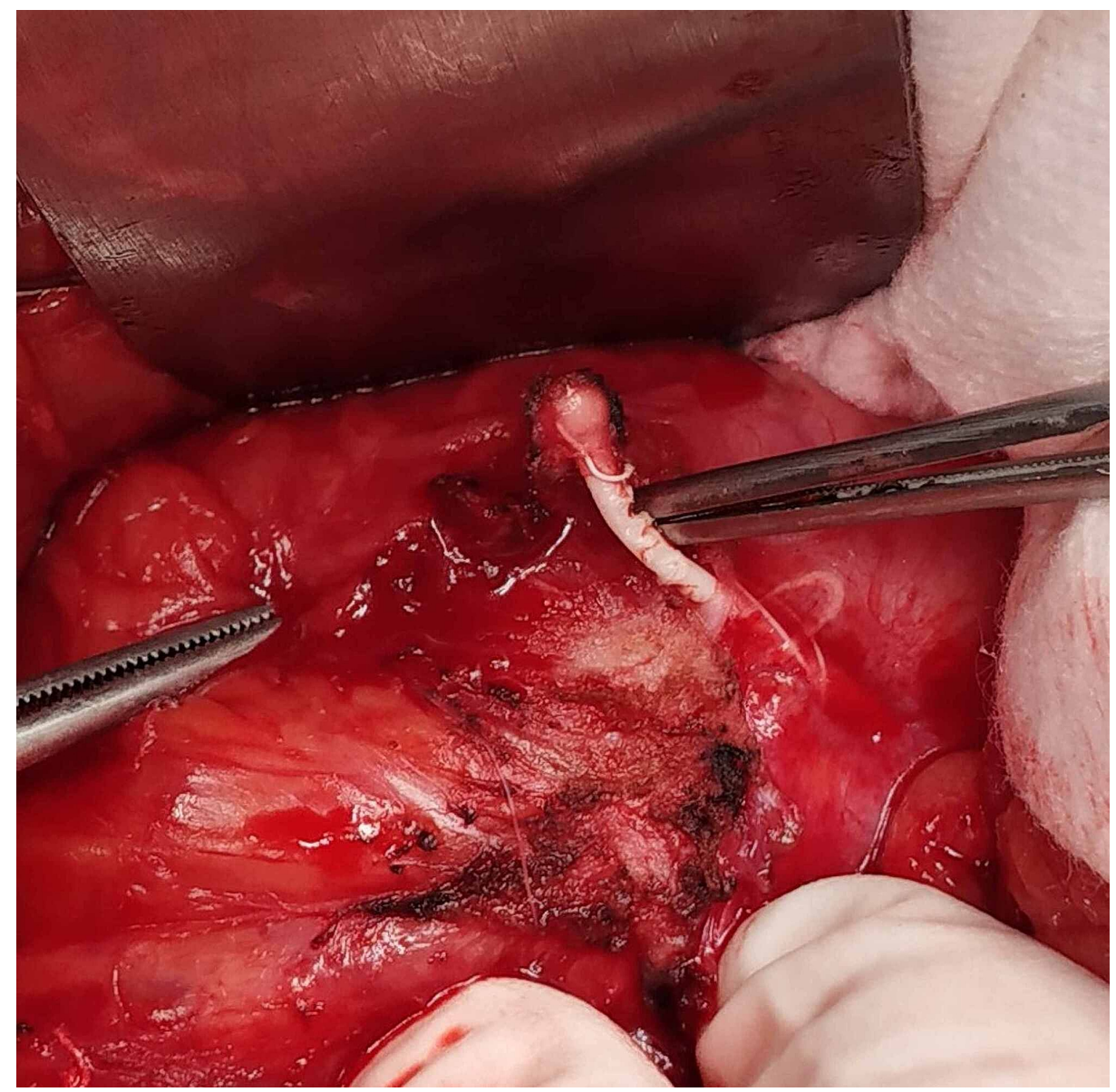

FIGURE 3: Intra-operative photograph showing the Intrauterine contraceptive devices (IUCD) in the anterior bladder wall

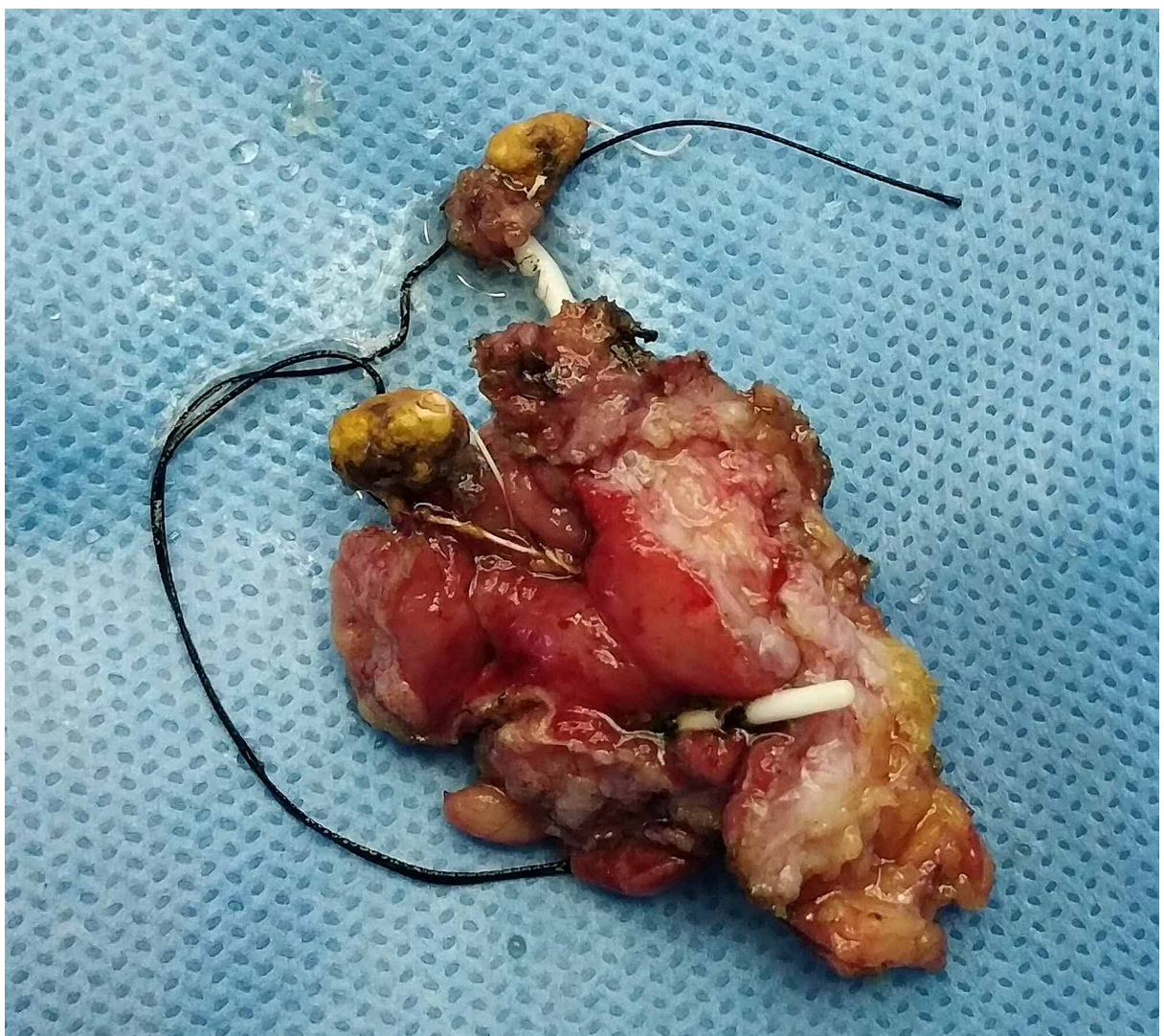




\section{Cureus}

FIGURE 4: Post-operative photograph of the excised bladder tissue with the Intrauterine contraceptive devices (IUCD) within the bladder wall

The details of the patients are noted in Table 1 .

\begin{tabular}{|l|l|l|l|l|}
\hline & Age (years) & Presenting symptom & Complication of IUCD & Management \\
\hline 1 & 40 & Lost threads of IUCD & Migration into bladder wall & Laparotomy + partial cystectomy \\
\hline 2 & 35 & Lower urinary tract symptoms & Bladder calculus on migrated IUCD & Laparotomy + partial cystectomy \\
\hline
\end{tabular}

TABLE 1: Characteristics of the patients

Studies which have described IUCD devices that have perforated into the bladder have been mentioned in Table 2. In 1999, Kassab et al reported an extensive literature search and found 23 instances of IUCD perforation into bladder (out of 165 perforations reported at the time). Out of the studies analyzed in the Pubmed search, a total of 25 relevant studies were included, as they had details on patient characteristics, time since insertion to presentation, presentation of patient, and details and outcome of management. In these, patients were identified. The most common presentation was a bladder calculus forming over a migrated IUCD (24/31 patients, 78\%). The second most common were embedded IUCD (outside the bladder 3/31 patients, 9.6\%), and IUCD in the bladder without a calculus (3/31, 9.6\%). Ureteric obstruction was reported in one patient $(1 / 31,3.2 \%)$. The management was surgical in all cases $(32 / 32,100 \%)$. Cystoscopic retrieval (including cystolitholapaxy) was the most common in 16 cases (53\%), followed by open vesicolithotomy in seven cases (24\%). No major intra-operative or post-operative complications were reported in any of these studies.

\begin{tabular}{|c|c|c|c|c|c|c|}
\hline & Authors & Year & Patient(s) & Complication & $\begin{array}{l}\text { Time since } \\
\text { insertion of IUCD }\end{array}$ & Management \\
\hline 1 & De Silva et al [6] & 2017 & One & $\begin{array}{l}\text { Bladder calculus on migrated } \\
\text { IUCD }\end{array}$ & 15 years & Open vesicolithotomy \\
\hline 2 & Sano et al [7] & 2017 & One & $\begin{array}{l}\text { Bladder calculus on migrated } \\
\text { IUCD }\end{array}$ & $>2$ years & Laser lithotripsy \\
\hline 3 & Sharma et al [8] & 2017 & One & $\begin{array}{l}\text { Bladder calculus on migrated } \\
\text { IUCD }\end{array}$ & 3 years & Cystoscopic removal \\
\hline 4 & Cheung et al [9] & 2018 & One & Migrated IUCD on bladder surface & 3 months & Laparotomy \\
\hline 5 & Shin et al [10] & 2011 & One & $\begin{array}{l}\text { Bladder calculus + embedded } \\
\text { IUCD }\end{array}$ & 10 years & Laparoscopic excision \\
\hline 6 & Waqar et al [1] & 2020 & One & $\begin{array}{l}\text { Bladder calculus on migrated } \\
\text { IUCD }\end{array}$ & 10 years & $\begin{array}{l}\text { Laser lithotripsy + transvaginal } \\
\text { removal }\end{array}$ \\
\hline 7 & $\begin{array}{l}\text { Priyadarshani et } \\
\text { al [11] }\end{array}$ & 2017 & One & Ureteric erosion + obstruction & 2 years & $\begin{array}{l}\text { Laparotomy + Ureteric } \\
\text { reimplantation }\end{array}$ \\
\hline 8 & Tan et al [12] & 2019 & One & $\begin{array}{l}\text { Bladder calculus + embedded } \\
\text { IUCD }\end{array}$ & 13 years & Laparotomy \\
\hline 9 & Alabi et al [13] & 2018 & One & $\begin{array}{l}\text { Bladder calculus + embedded } \\
\text { IUCD }\end{array}$ & 17 years & $\begin{array}{l}\text { Laparoscopic + cystoscopic } \\
\text { removal }\end{array}$ \\
\hline 10 & $\begin{array}{l}\text { Al-Awadi et al } \\
{[14]}\end{array}$ & 2011 & One & $\begin{array}{l}\text { Bladder calculus on migrated } \\
\text { IUCD }\end{array}$ & 25 years & Open Vesicolithotomy \\
\hline 12 & Olaore et al [15] & 1999 & One & Migration of IUCD into bladder & 1 year & Cystoscopic removal \\
\hline 13 & $\begin{array}{l}\text { Amin and } \\
\text { Mehmood [16] }\end{array}$ & 2009 & One & $\begin{array}{l}\text { Bladder calculus on migrated } \\
\text { IUCD }\end{array}$ & 10 years & Open Vesicolithotomy \\
\hline 14 & Rafique [17] & 2002 & One & Bladder calculus on migrated & & Cystoscopic removal \\
\hline
\end{tabular}




\section{Cureus}

\begin{tabular}{|c|c|c|c|c|c|c|}
\hline & & & & IUCD & & \\
\hline 15 & $\begin{array}{l}\text { Ahmed and } \\
\text { Ogunleye [18] }\end{array}$ & 2013 & One & $\begin{array}{l}\text { Bladder calculus on migrated } \\
\text { IUCD }\end{array}$ & 10 years & Open Vesicolithotomy \\
\hline 16 & Bashir et al [19] & 2016 & One & $\begin{array}{l}\text { Bladder calculus on migrated } \\
\text { IUCD }\end{array}$ & 12 years & Open Vesicolithotomy \\
\hline 17 & Jeje et al [20] & 2012 & One & IUCD migrated into bladder wall & 20 years & \\
\hline 18 & Ko et al [21] & 2011 & Two & $\begin{array}{l}\text { 1. Migrated into bladder wall } 2 . \\
\text { Migrated into bladder }\end{array}$ & & $\begin{array}{l}\text { 1. Cystoscopic retrieval } 2 . \\
\text { Cystoscopic retrieval }\end{array}$ \\
\hline 19 & $\begin{array}{l}\text { Aggarwal et al } \\
\text { [22] }\end{array}$ & 2014 & One & $\begin{array}{l}\text { Bladder calculus on migrated } \\
\text { IUCD }\end{array}$ & 5 years & Open Vesicolithotomy \\
\hline 20 & Nouira et al [5] & 2007 & Six & $\begin{array}{l}\text { Bladder calculi All migrated } \\
\text { IUCD's }\end{array}$ & & Cystoscopic retrieval in all \\
\hline 21 & Basiri et al [23] & 2019 & One & $\begin{array}{l}\text { Bladder calculus on migrated } \\
\text { IUCD }\end{array}$ & 11 years & $\begin{array}{l}\text { Cystoscopic excision from } \\
\text { bladder wall }\end{array}$ \\
\hline 22 & $\begin{array}{l}\text { Christodoulides } \\
\text { [24] }\end{array}$ & 2020 & One & $\begin{array}{l}\text { Bladder calculus on migrated } \\
\text { IUCD }\end{array}$ & 20 years & Cystoscopic removal \\
\hline 23 & Ozcelik et al [25] & 2003 & One & $\begin{array}{l}\text { Bladder calculus on migrated } \\
\text { IUCD }\end{array}$ & 6 months & Cystoscopic retrieval \\
\hline 24 & Dede et al [26] & 2006 & One & $\begin{array}{l}\text { Bladder calculus on migrated } \\
\text { IUCD }\end{array}$ & $\sim 5$ years & $\begin{array}{l}\text { Laparoscopic + cystoscopic } \\
\text { retrieval }\end{array}$ \\
\hline 25 & Pare et al [27] & 2020 & One & Migration into bladder & 18 months & Cystoscopic retrieval \\
\hline
\end{tabular}

TABLE 2: Review of relevant papers on IUCD migration into bladder

\section{Discussion}

IUCD is a widely accepted method of contraception. It is easily inserted, is reversible by removal, and causes few side effects [1]. The common side effects are abdominal pain, and heavy menstrual bleeding, especially in the first few months after insertion. Rarely, expulsion, menorrhagia, dysmenorrhoea, pregnancy, and abortion may occur.

IUCD's can perforate the uterus and then migrate into the pelvic or abdominal spaces. IUCD perforations have been divided into four types according to the anatomical spaces affected. The first compartment is the uterine cavity (type 1), the second is when the IUCD is confined to the myometrium (type 2) and the third compartment is when the peritoneal cavity is breached (type 3). When an IUCD penetrates the surrounding viscera, the perforation is type 4 [6].

A uterine perforation may be primary or secondary. A primary perforation occurs at the time of insertion, whereas a secondary perforation occurs after a delay, probably due to pressure necrosis and inflammation of the uterine wall. $[2,28,29]$

IUCD migration may follow uterine perforation. It is a rare complication, occurring between $1.2-1.6$ per 1,000 insertions [8] Mechanisms that explain migration of an IUCD include iatrogenic perforation, spontaneous uterine contractions, involuntary bladder contraction, gut peristalsis, and peritoneal fluid movement which together contribute to the migration and implantation of the IUCD in other adjacent organs. IUCD's have most commonly been found in the Pouch of Douglas. They have been found in the ceacum, the bladder, and adjacent to the ureter. Kassab reported 165 perforations of the IUCD with the IUCD located in various organs [3].

IUCD migration into the bladder is a rare complication and most commonly occurs between two and 10 years after implantation. In the first case of this series, the migration was detected three years after insertion, and in the second case, migration was detected after 12 months.

After being in the bladder for a long time, encrustations form over the limbs of the IUCD which can then form a vesical calculus [5]. Rarely, the IUCD can embed in the wall of the bladder and be difficult to remove, necessitating a cystotomy or a partial cystectomy [9]. 


\section{Cureus}

The initial approach to surgery in the first case was laparoscopic. However, due to dense adhesions between the IUCD and the surrounding tissue including the bladder, conversion to laparotomy was required. A partial cystectomy was needed in this patient. Shin et al demonstrated the use of laparoscopic approach alone to manage an embedded IUCD [10]

Sharma et al performed a cystoscopic retrieval of an intravesical IUCD [11]. Sano et al have described a case in which laser lithotripsy was used to remove a bladder calculus under general anaesthesia [12]. In the second case of our series, this was attempted, but the limbs of the IUCD were embedded in the wall of the bladder and covered with a calculus and the procedure could not be safely performed. This necessitated a thorough evaluation and subsequent laparotomy.

Of the twenty-six papers that have been cited in Table 2, 18 papers (69.2\%) have been published in the last decade alone. A growing world population along with an increase in the use of contraception worldwide, as is evidenced by falling birth rates, translates to a potential increase in the incidence of IUCD migration in the coming years. Doctors treating women with potential complications of IUCD insertion need to be aware of this fact.

Based on the published data, an algorithm is suggested for the management of patients with migrated IUCD's that may involve the urinary tract (Figure 5).

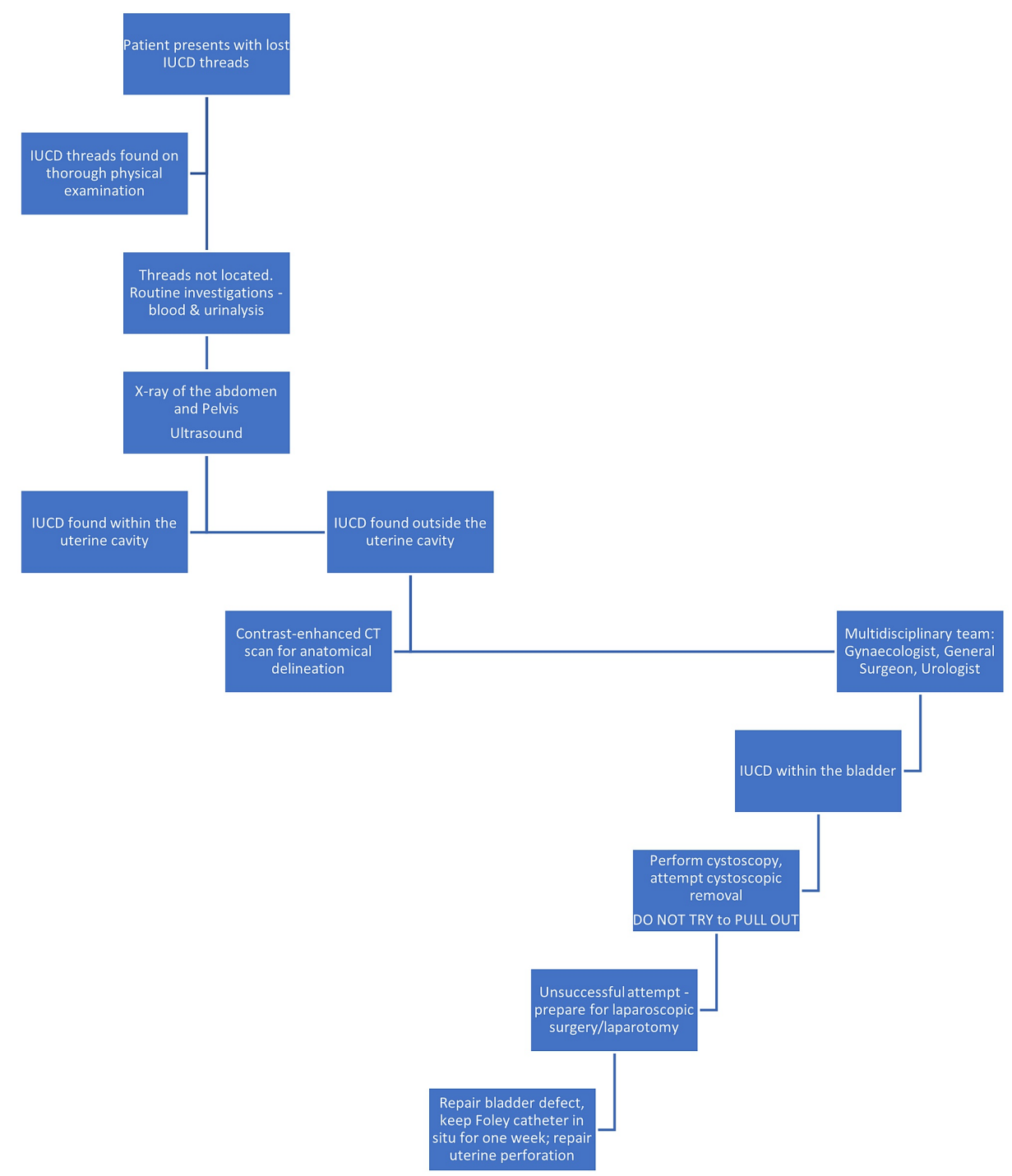

FIGURE 5: A suggested algorithm for management of migrated IUCD

\section{Conclusions}

Most IUCD migrations occur at the time of insertion, and proper training of healthcare workers is imperative to prevent complications. Although rare, IUCD migration is a complication with high morbidity. IUCD 
migration into the bladder is a debilitating condition for the patient and warrants a multi-disciplinary approach with the use of imaging techniques and cystoscopy to locate the IUCD. Proper patient preparation is vital to a successful outcome. With an increasing number of women worldwide adopting some form of contraception, including IUCD, the incidence of migrated IUCD's is going to rise in the future, and gynecologists, surgeons, and urologists need to be aware of this complication.

\section{Additional Information \\ Disclosures}

Human subjects: Consent was obtained or waived by all participants in this study. Animal subjects: All authors have confirmed that this study did not involve animal subjects or tissue. Conflicts of interest: In compliance with the ICMJE uniform disclosure form, all authors declare the following: Payment/services info: All authors have declared that no financial support was received from any organization for the submitted work. Financial relationships: All authors have declared that they have no financial relationships at present or within the previous three years with any organizations that might have an interest in the submitted work. Other relationships: All authors have declared that there are no other relationships or activities that could appear to have influenced the submitted work.

\section{References}

1. Waqar M, Moubasher A, Ameen T, Robinson D, Walker NF: Erosion of an intrauterine contraceptive device into the urinary bladder: a case report. Case Rep Womens Health. 2020, 29:00274.

2. Esposito JM, Zarou DM, Zarou GS: A Dalkon Shield imbedded in a myoma: case report of an unusual displacement of an intrauterine contraceptive device. Am J Obstet Gynecol. 1973, 15:578-81. 10.1016/00029378(73)90128-2

3. Kassab B, Audra P: The migrating intrauterine device. case report and review of the literature (Article in French). Contracept Fertil Sex. 1999, 27:696-700.

4. Kaplanoğlu M, Bülbül M, Yüce T, Kaplanoğlu D, Aban M: Mislocated extrauterine intrauterine devices: diagnosis and surgical management. J Turk Ger Gynecol Assoc. 2015, 1:91-5. 10.5152/jtgga.2015.15243

5. Nouira Y, Rakrouki S, Gargouri M, Fitouri Z, Horchani A: Intravesical migration of an intrauterine contraceptive device complicated by bladder stone: a report of six cases. Int Urogynecol J Pelvic Floor Dysfunct. 2007, 18:575-8. 10.1007/s00192-006-0157-z

6. De Silva WSL, Kodithuwakku KASUA, Aponsu GUE, Rathnayake RMM, Rajasegaram E: A large bladder stone caused by the intravesical migration of an intrauterine contraceptive device: a case report. J Med Case Rep. 2017, 22:293-10. 10.1186/s13256-017-1461-6

7. Sano M, Nemoto K, Miura T, Suzuki Y: Endoscopic treatment of intrauterine device migration into the bladder with stone formation. J Endourol Case Rep. 2017, 1:105-107. 10.1089/cren.2017.0038

8. Sharma A, Andankar M, Pathak H: Intravesical migration of an intrauterine contraceptive device with secondary calculus formation. Korean J Fam Med. 2017, 38:163-165. 10.4082/kifm.2017.38.3.163

9. Cheung ML, Rezai S, Jackman JM, et al.: Retained intrauterine device (IUD): triple case report and review of the literature. Case Rep Obstet Gynecol. 2018, 9362962. 10.1155/2018/9362962

10. Shin DG, Kim TN, Lee W: Intrauterine device embedded into the bladder wall with stone formation: laparoscopic removal is a minimally invasive alternative to open surgery. Int Urogynecol J. 2012, 23:1129-31. 10.1007/s00192-011-1632-8

11. Priyadarshi V, Sehgal N, Sen D: Ureteric erosion and obstruction: a rare but dreaded complication of intrauterine contraceptive device. Urol Ann. 2017, 9:103-106. 10.4103/0974-7796.198839

12. Tan JH, Lip H, Ong W, Omar S: Intrauterine contraceptive device embedded in bladder wall with calculus formation removed successfully with open surgery. Malays Fam Physician. 2019, 31:29-31.

13. Alabi TO, Keshavamurthy M, Ahmed S, Ojewola RW, Jain M, Tijani KH: Combined laparoscopic and cystoscopic retrieval of forgotten translocated intrauterine contraceptive device. Niger J Surg. 2018, 24:4851. 10.4103/njs.njs_18_17

14. Al-Awadi KA, Zaghloul AS, Kehinde EO: Symptomatic secondary vesical calculus formed on an intrauterine contraceptive device inserted 25 years previously. Urol Int. 2011, 86:483-6. 10.1159/000323854

15. Olaore JA, Shittu OB, Adewole IF: Intravesical Lippes loop following insertion for the treatment of Asherman's syndrome: a case report. Afr J Med Med Sci. 1999, 28:207-8.

16. Amin U, Mahmood R: An unusual vesical calculus. J Radiol Case Rep. 2009, 3:10-3. 10.3941/jrcr.v3i2.113

17. Rafique M: Vesical calculus: a complication of intravesical migration of intrauterine contraceptive device . Int Urogynecol J Pelvic Floor Dysfunct. 2002, 13:380-2. 10.1007/s001920200084

18. Abdulwahab-Ahmed A, Ogunleye OO: Vesical calculus 10 years post missing intrauterine contraceptive device. J Surg Tech Case Rep. 2013, 5:48-50. 10.4103/2006-8808.118630

19. Bashir BM, Atobatele MO, Illo HG: Bladder calculus resulting from an intravesical translocation of intrauterine contraceptive device in a postmenopausal woman. Niger J Med. 2016, 25:90-2.

20. Jeje EA, Ojewola RW, Atoyebi OA: Intravesical migration of a failed and forgotten intrauterine contraceptive device after 20 years of insertion--a case report. Nig Q J Hosp Med. 2012, 22:91-3.

21. Ko PC, Lin YH, Lo TS: Intrauterine contraceptive device migration to the lower urinary tract: report of 2 cases. J Minim Invasive Gynecol. 2011, 18:668-70. 10.1016/j.jmig.2011.05.010

22. Aggarwal S, Jindal RP, Deep A: Intravesical migration of intrauterine contraceptive devices with stone formation. J Family Med Prim Care. 2014, 3:449-51. 10.4103/2249-4863.148147

23. Basiri A, Shakiba B, Rostaminejad N: Removal of intramural trapped intrauterine device by cystoscopic incision of bladder wall. Int Braz J Urol. 2019, 45:408-409. 10.1590/S1677-5538.IBJU.2018.0056

24. Christodoulides AP, Karaolides T: Intravesical migration of an intrauterine device (IUD)-case report. Urology. 2020, 139:14-17. 10.1016/j.urology.2020.02.009 


\section{Cureus}

25. Ozçelik B, Serin IS, Basbug M, Aygen E, Ekmekçioglu O: Differential diagnosis of intra-uterine device migrating to bladder using radiographic image of calculus formation and review of literature. Eur J Obstet Gynecol Reprod Biol. 2003, 1:94-6. 10.1016/s0301-211500240-3

26. Dede FS, Dilbaz B, Sahin D, Dilbaz S: Vesical calculus formation around a migrated copper-T 380-A . Eur J Contracept Reprod Health Care. 2006, 11:50-2. 10.1080/13625180500389349

27. Paré AK, Ouattara A, Yé D, Kabré B, Bako A, Abubakar BM, Kambou T: Management of intrauterine device migrated into the bladder: a case report and literature review. Case Rep Urol. 2020, 31:8850087. 10.1155/2020/8850087

28. Zakin D, Stern WZ, Rosenblatt R: Perforated and embedded intrauterine devices. JAMA. 1982, 16:2144-6.

29. Harrison-Woolrych M, Ashton J, Coulter D: Uterine perforation on intrauterine device insertion: Is the incidence higher than previously reported?. Contraception. 2003, 67:53-6. 10.1016/s0010-7824(02)00417-1 